
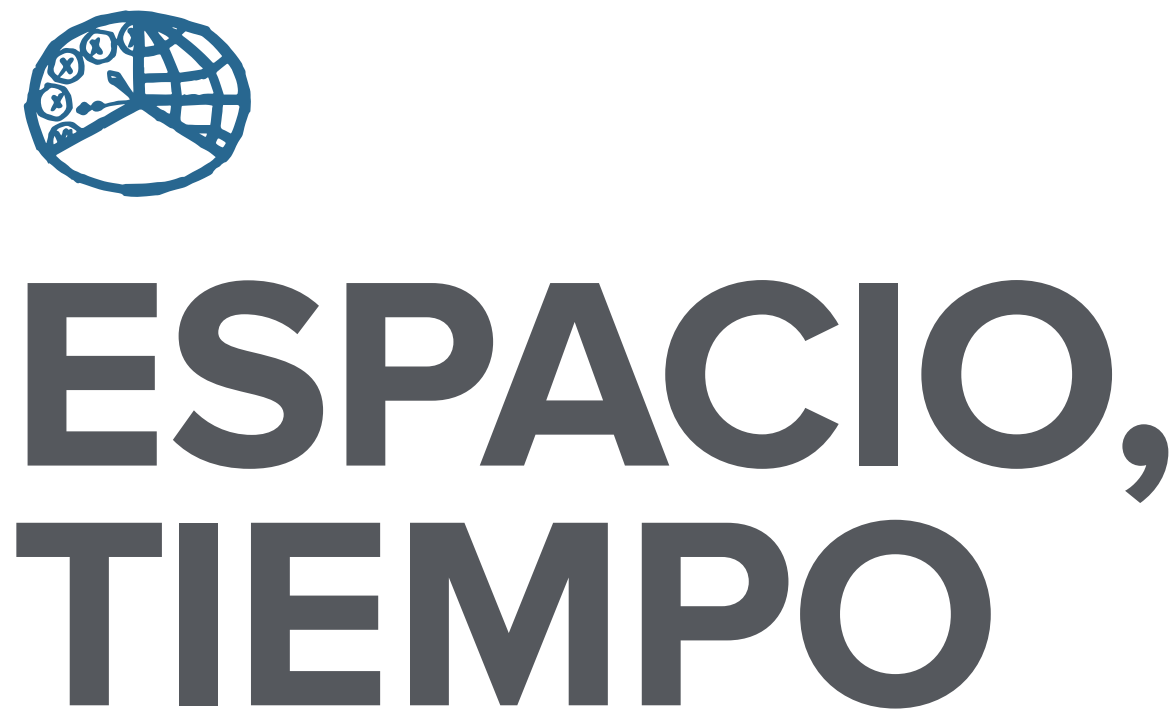

AÑO 2016

NUEVA ÉPOCA

ISSN 1130-4715

E-ISSN 2340-1478
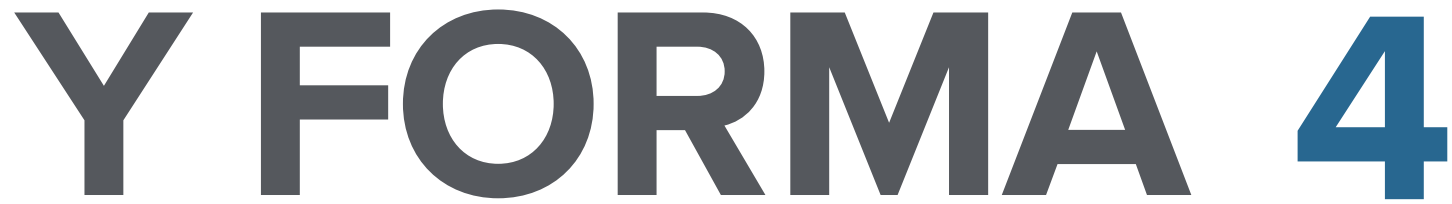

SERIE VII HISTORIA DEL ARTE

REVISTA DE LA FACULTAD DE GEOGRAFÍA E HISTORIA 

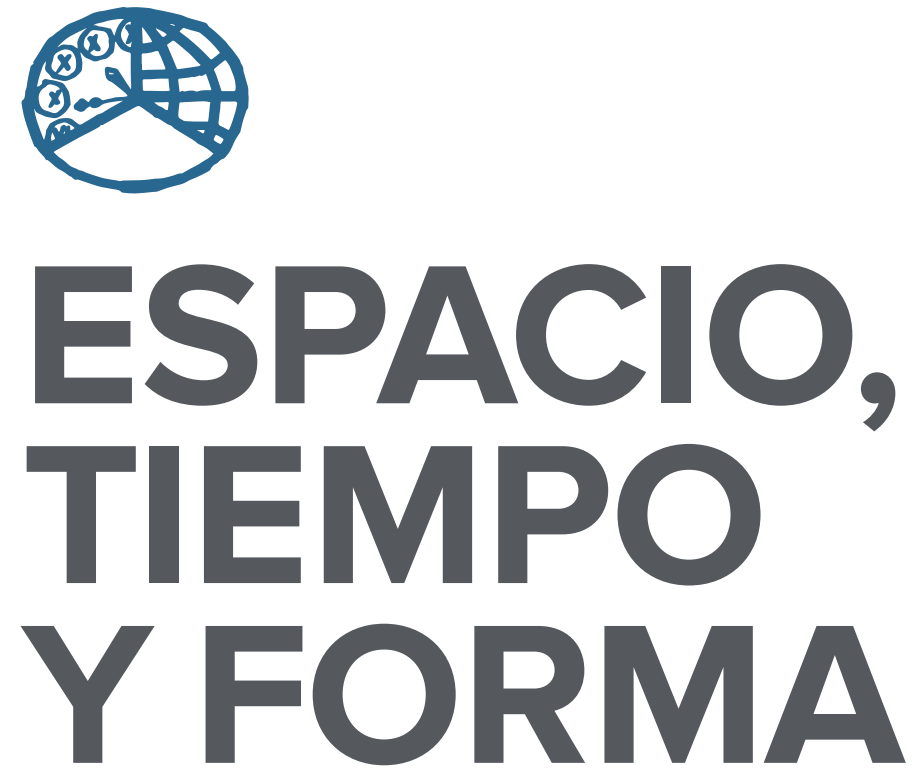

AÑO 2016

NUEVA ÉPOCA

ISSN $1130-4715$

E-ISSN 2340-1478

SERIE VII HISTORIA DEL ARTE

REVISTA DE LA FACULTAD DE GEOGRAFÍA E HISTORIA

DOI: http://dx.doi.org/10.5944/etfvii.4.2016

\section{UกED}

UNIVERSIDAD NACIONAL DE EDUCACIÓN A DISTANCIA 
La revista Espacio, Tiempo y Forma (siglas recomendadas: ETF), de la Facultad de Geografía e Historia de la UNED, que inició su publicación el año 1988, está organizada de la siguiente forma:

$$
\begin{aligned}
& \text { SERIE I - Prehistoria y Arqueología } \\
& \text { SERIE II - Historia Antigua } \\
& \text { SERIE III - Historia Medieval } \\
& \text { SERIE IV - Historia Moderna } \\
& \text { SERIE V - Historia Contemporánea } \\
& \text { SERIE VI - Geografía } \\
& \text { SERIE VII - Historia del Arte }
\end{aligned}
$$

Excepcionalmente, algunos volúmenes del año 1988 atienden a la siguiente numeración:

$$
\begin{aligned}
& \mathrm{N}^{\circ} 1 \text { - Historia Contemporánea } \\
& \mathrm{N}^{\circ} 2 \text { - Historia del Arte } \\
& \mathrm{N}^{\circ} 3 \text { - Geografía } \\
& \mathrm{N} .^{\circ} 4 \text { - Historia Moderna }
\end{aligned}
$$

ETF no se solidariza necesariamente con las opiniones expresadas por los autores.

\author{
UNIVERSIDAD NACIONAL DE EDUCACIÓN A DISTANCIA \\ Madrid, 2016 \\ SERIE VII · HISTORIA DEL ARTE (NUEVA ÉPOCA) N. ${ }^{\circ} 4,2016$ \\ ISSN $1130-4715 \cdot$ E-ISSN 2340-1478 \\ DEPÓSITO LEGAL \\ $M-21.037-1988$ \\ URL \\ ETF VII · HISTORIA DEL ARTE · http://revistas.uned.es/index.php/ETFVII \\ DISEÑO Y COMPOSICIÓN \\ Carmen Chincoa Gallardo · http:/www.laurisilva.net \\ Impreso en España · Printed in Spain
}

(c) (1) (8) Esta obra está bajo una licencia Creative Commons Reconocimiento-NoComercial 4.0 Internacional. 


\section{DOSSIER}

ART MOVES:

PERFORMATIVITY IN TIME, SPACE AND FORM

by Mieke Bal

EL ARTE (SE) MUEVE:

PERFORMATIVIDAD EN EL TIEMPO, EL ESPACIO Y LA FORMA

por Mieke Bal 


\section{DOSSIER}

FIRST REFLECTIONS ON MOVEMENT 


\title{
SURFACE EXPLORATIONS: 3D MOVING IMAGES AS CARTOGRAPHIES OF TIME
}

\section{EXPLORACIONES DE SUPERFICIE: IMÁGENES 3D EN MOVIMIENTO COMO CARTOGRAFÍAS DEL TIEMPO}

\author{
Nanna Verhoeff ${ }^{1}$ \\ Received: 28/10/2015 - Approved: 29/02/2016 \\ DoI: http://dx.doi.org/10.5944/etfvii.4.2016.15497
}

\begin{abstract}
Moving images of travel and exploration have a long history. In this essay I will examine how the trope of navigation in 3D moving images can work towards an intimate and haptic encounter with other times and other places. The particular navigational construction of space in time in $3 \mathrm{D}$ moving images can be considered as a cartography of time. This is a haptic cartography of exploration of the surfaces on which this encounter takes place. Taking Werner Herzog's film Cave of Forgotten Dreams (20I0) as a theoretical object, the main question addressed is how the creative exploration of new visualization technologies -here: from rock painting, and principles of animation, to 3D moving images- entails an epistemological inquiry into, and statements about, the power of images, technologies of vision, and the media cartographies they make. I am interested in the way in which the film shows how its technology is not a mere gimmick but rather a tool for exploring space and time in new ways. In other words, in my analysis of the film, I aim to explore how it invites an exploration of its own means for exploration. These questions turn new technologies into relevant sources for cultural, historical and philosophical reflection.
\end{abstract}

\section{Keywords}

3D moving image; cartography; navigation; animation; haptic visuality; surface; archeology; visualization.

\section{Resumen}

Las imágenes en movimiento del viaje y de la exploración tienen una larga tradición. En este artículo examinaré cómo el tropo de la navegación en las imágenes en tres dimensiones puede crear un encuentro íntimo y háptico con otros tiempos y otros lugares. La particular construcción relativa a la navegación del espacio en el tiempo en las imágenes en tres dimensiones puede ser considerada como una cartografía

1. Utrecht University (n.verhoeff@uu.nl). 
del tiempo. Esta es una cartografía háptica de la exploración de superficies en las cuales ese encuentro tiene lugar. Tomando el film de Werner Herzog Cueva de los sueños olvidados (2010) como un objeto teórico, la cuestión principal que se formula es cómo la exploración creativa de las nuevas tecnologías de la visualización - ya sea desde la pintura sobre rocas, y los principios de animación, hasta las imágenes en tres dimensiones - implica una investigación epistemológica, con las consecuentes afirmaciones, sobre el poder de las imágenes, las tecnologías de la visión y los medios cartográficos que ellos crean. Estoy interesada en el modo en que el film muestra cómo su tecnología no es un mero truco sino más bien una herramienta para explorar el espacio y el tiempo de nuevas maneras. En otras palabras, en mi análisis de la película pretendo explorar cómo invita a la exploración por sus propios medios de exploración. Estas cuestiones convierten las nuevas tecnologías en fuentes relevantes para la reflexión cultural histórica y filosófica.

Palabras clave

Imagen 3D en movimiento, navegación, animación, visualidad háptica, superficie, arqueología, visualización. 


\section{EXPLORATIONS}

Werner Herzog's Cave of Forgotten Dreams (2010), a 3D documentary about the prehistoric cave paintings in Chauvet in the South of France, raises questions about the relationship between image, technology, and epistemology. The film shows striking and vibrant Paleolithic drawings, mostly of animals, of more than 30.000 years ago. The depiction of galloping herds of animals is characterized by a high sense of motion and the bulges and contours of the rocky surface create a striking effect of three-dimensionality to the images. By navigating through the space the film camera charts the spatial structure of the cave with its labyrinth of corridors, walls, niches, and chambers. Moreover, while watching the descent and following the explorers very closely, one can almost feel the humid chill they experience in the depth of the rock formation. Characteristic of the film's visual style are the long tracking shots moving along the rock's walls, usually sideways, produced by the explorer-camera person. The voice-over informs us of the difficulty in getting access and how this is the first, and perhaps only time that a camera is allowed in the cave. Well-aware of the uniqueness of this moment, the viewer gets the sense that the explorative gaze of the film crew who enters the cave for the first time parallels her gaze as a spectator. This second-hand or visual exploration of space, so characteristic of travelogues and other types of moving-image navigation brings a sense of simultaneity, of liveness to the filmic experience.

While the connection to colonial and imperialist, and gendered, tropes of spatial exploration is clear, the film also speaks to a self-reflexivity in visual media forms that explore and investigate the specificities of their (new) technologies and processes of visualization. In this case of cinematic archeological exploration, the movie suggest how moving images of spatial navigation can construct, what we may call, a haptic cartography of time. Whereas one may argue that all films map narratives spatiotemporally because they are time-based representations of space, in this case of $3 \mathrm{D}$ navigational imagery something more is at stake. The mobile camera's navigation of the cave, its documentation of the surfaces, and its mode of exploration put us back in touch with another (image) time, extending the historical layering of the filmic image and, as I will argue below, augmenting the cartographic in this experience of navigation as a cartography in-the-making. Departing from the notion that moving as well as still images give expression, not only to their contents or subject matter but, more importantly, to the relationships between the seer and the seen, I would propose that the film itself, its mode of filming and editing, offers a distinct form of knowledge production countering other, perhaps more traditional visual methods that are anchored in distanced objectification of the objects studied.

The film experiments with and reflects on another aspect of exploration: not of discovery, dissection and containment, but of alternative ways of seeing itself. As such, it explores exploration. Here, «seeing itself» is staged as an encounter an encounter at the surface. As Giuliana Bruno examines in her recent impressive study the many surfaces that surround us function as connecting tissue, as meeting 
places that connect bodies, subjects, materials. ${ }^{2}$ Following her approach to surfaces as sites for material relations, mediation can be conceived of as the process that takes place on the surface - irrespective of the fundamental phenomenological characteristics of material and sensory qualities that surfaces may have. This primary and inherently sensuous encounter can be re-mediated at another surface on which this new encounter takes place. This is a layering of sorts. And these surfaces connect via technologies of representation. Therefore, I am interested in the way this film as a study of exploration and visualization, provides an opportunity to think differently about the epistemological and theoretical stakes of mediated vision. In the case of the time travel that the films portray, it endeavors to produce a counter-cartography of time in time, in which the co-presence of two worlds - of viewer and image - is traced on the contours of the surface.

\section{MOVING IMAGES}

Explorations concern the potential power of images to move us. Being «moved» is an alternative to distancing mastery; going along is a very different attitude from taking possession; from capture. $3 \mathrm{D}$ technology can help us to develop and practice, and also understand and be aware of this attitude in looking. Space in $3 \mathrm{D}$ is not represented on a structured plane with a fixed vanishing point, but allows a closer engagement with the movements through space as well as time. But technology does not operate in cultural isolation. Indeed, Jihoon Kim has suggested that $3 \mathrm{D}$ moving images perhaps first and foremost invite investigation of «archaeological, aesthetic, cultural and industrial underpinnings suggested by 3D's varying forms from the predigital through to the digital age.»3 Expanding this cultural and historical framing of $3 \mathrm{D}$ imagery, my argument here departs from the assessment of 3D imagery as a technology for visualization, but ultimately focuses on the reflection on the potential relational implications of spatial exploration and navigation, and the visuality this produces. My questions are fundamentally about the haptic and spatiotemporal underpinnings of (visual) navigation that Herzog's $3 \mathrm{D}$ documentary addresses, and through which the meanings of the technology come into purview. In other words, I am interested in the way the film explores, and invites an exploration of, its own means for exploration.

In particular, this $3 \mathrm{D}$ documentary suggests a haptic mode of visualization that is experimental in essence, and (hence) self-reflexive in its use of moving-image technologies and the way we can visualize, beyond our usual limitations, what is elsewhere and elsewhen - to examine another place and time. To be accessible, this

2. Bruno, Giuliana: Surface: Matters of Aesthetics, Materiality. Chicago, IL, University of Chicago Press, 2014.

3. KIM, Jihoon: «Introduction: Three dimensionality as a heuristic device», Convergence: The International Journal of Research into New Media Technologies, 19, 4 (2013), pp. 391-395, p. 392. About 3D technology and the role of Herzog's Cave of Forgotten Dreams in the introduction of digital 3D in European art houses, see CHRISTIE, lan: «Will the 3D Revolution Happen? A Brief Perspective on the Long History of Stereoscopy (with Special Thanks to Eisenstein and Bazin)» in Annie van den Oever (ed.), Technë/Technology, Amsterdam, Amsterdam University Press, 2015, pp. 115-135. 
«elseness» needs visualization, mediation, which unsettles the habitual nature of seeing and the close relationship between haptic experience and knowledge. Across time and space, it addresses a spectator explicitly situated in the «here» and «now.» In order to stage a more or less intimate and close encounter, the elseness -as a spatial and temporal conception of «otherness»- demands a direct engagement of the subject with this evocative confrontation with the past in a mix of observant reflection and communicative affect. This engagement puts the body of the spectator in the center of the event of viewing.

As an alternative to traditionally more distant (and distancing) modes of knowledge production in a haptic cartography of time, as we may call it, Cave of Forgotten Dreams explores the nature of exploration as such. The cave of the title is visually excavated as both an archeological site and a location-based image archive. ${ }^{4}$ In the mode of an expedition or travelogue, the film provides access to the depths of the cave and allows the viewer-visitor to look around. But caves are never neutral spaces. In Plato's allegory of the cave a hollow space stands for the deceptiveness of representation. In Fritz Lang's Metropolis (1927) it evokes the social subjection of workers. In neither case the somewhat facile yet persistent association with female genitalia Freud brought to our attention is entirely absent. It is this near-inevitable but banal genderization and allegoric reading of the cave that Herzog's film - while certainly alluding to it in the poetic and melancholic voice-over - also counters through a variety of modes. Beside the more poetic and nostalgic undertones it invites reflection on visualization as a time-based mode of intellectual exploration. A central strategy for this reflection is the bringing to the fore of the tension inherent in the cinematic moving image between a more or less habitual desire for visual exploration and immersion on the one hand, and a resistance against these ambitions on the other.

That the production of knowledge is at stake -in this case, in the clearly traditional rhetoric of the film poster used for advertising, of the «lost masterpiece» from an ancient moment in human culture- becomes clear in Herzog's voice-over, as well as in the interviews with the scientists who explore and analyze the cave. They all ask questions about the meaning of the images and speak of the wonderment before, and (in)accessibility of these meanings. Instead of a sober, scientific exploration with a clear goal of opening up and mapping by traversing and dissecting the cave, in their explanation of their analytical methods the scientists insist on an epistemological modesty. A document of archeological as well as cartographic exploration, this $3 \mathrm{D}$ movie provides visually powerful images that evoke a haptic and sensuous encounter with the space of the cave, the texture of the rock formations, and the layers, relief and curves of the paintings. I argue that the film creates

4. Akira Mizuta Lippit speaks about a «cryptographic archive» in the case of the cave of Lascaux: «For many, those images form a vast cryptographic archive, the key to a material history of language and thought as forms of graphic expression.» LIPPIT, Akira Mizuta: «Arche Texts: Lascaux, Eros, and the Anamorphic Subject», Discourse, 24, 2 (2002), pp. 18-2, p. 20. 


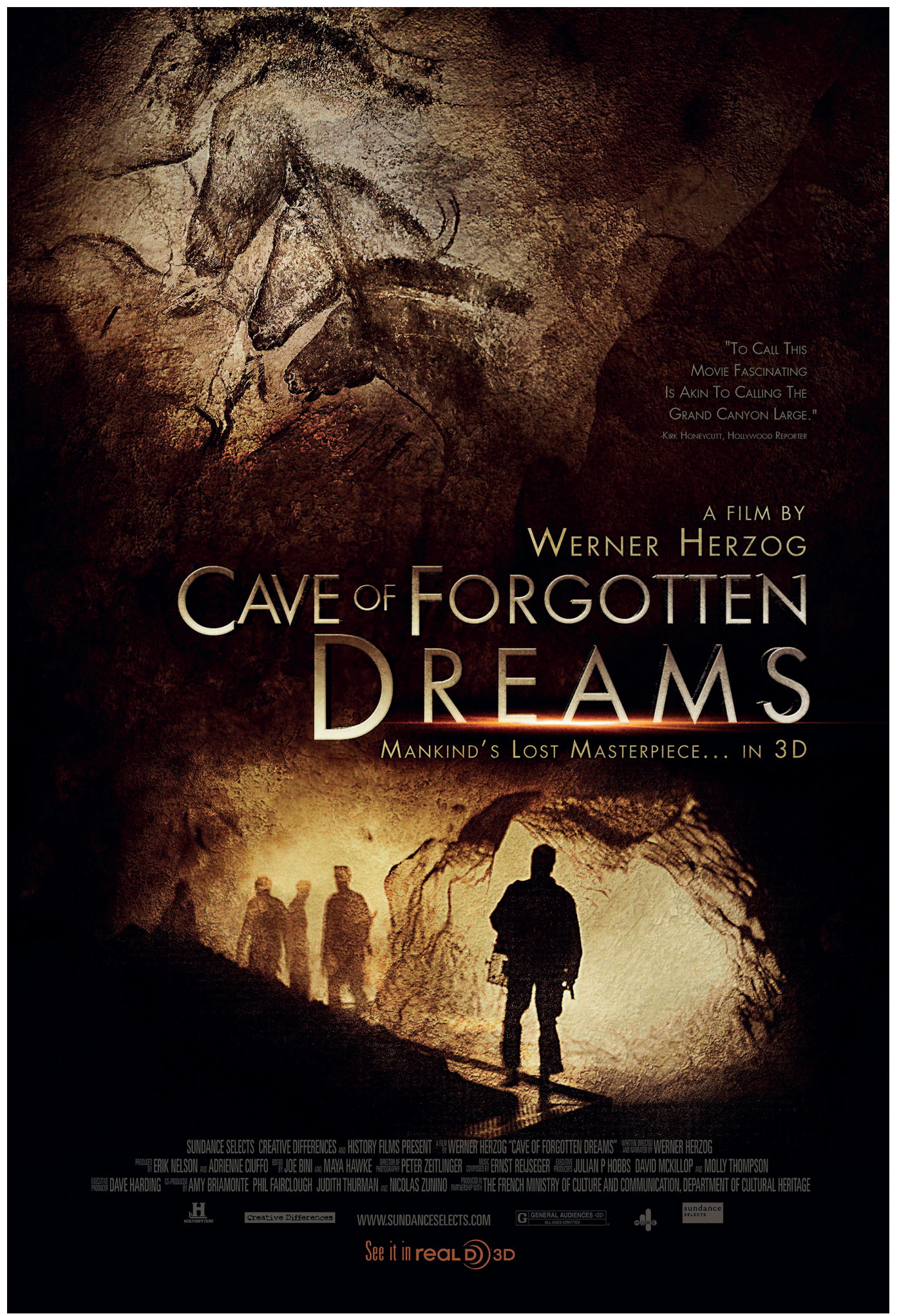

FIGURE 1: POSTER FOR THE MOVIE, SHOWING A DETAIL OF A GROUP OF GALLOPING HORSES, AND A SHOT OF THE FILMMAKERS/EXPLORERS WHO DESCEND INTO THE DEPTHS OF THE CAVE. 
an auratic presence - in Walter Benjamin's sense - as well as a temporal present, of the deep history of the place. ${ }^{5}$

To begin with, the film questions the dichotomy of moving versus still images, a dichotomy that, paradoxically, fixates movement. Herzog's film stages an encounter between the (doubly) moving image of the tracking shot and the technically still images of the cave drawings on their silent walls that are brought to life by light and (camera) movement - a feature that Herzog himself calls «cinematic.» ${ }^{6}$ In the following I address the multi-layeredness of both still and moving images of spatial (cartographic) and temporal (archeological) exploration as moving in multiple directions and temporalities- past, present, and future. Hence, the film is three-dimensional not only in spatial-visual terms, but also in temporality. One mode of transforming traditional exploration is the bond the film establishes between exploration and animation. ${ }^{7}$

\section{ANIMATION IN NAVIGATION}

The film's potential for dialogic encounter shows itself at the intersection of animation and exploration. The former brings space into time: in duration and into the present. The latter is a particularly haptic and navigational form of spatiotemporal mobility. Animation is, indeed, the art of difference and transformation. I take this conception of animation from South-African artist William Kentridge as he explains his stop-motion animation technique of constantly revised charcoal sketches. The succession of changing images gives life to images by setting them in motion. His signature method is one of palimpsestic -rather than serial-re-drawing and erasing of the same image with slight differences of which he manually shoots film frames. These drawings-for-projection are emphatically contemporary; the subject matter of his work deals very much with the (re-)writing and (re-)imaging of history. ${ }^{8}$ Yet,

5. BenJAMIN, Walter: «The Work of Art in the Age of Mechanical Reproduction», Illuminations. New York, Schocken, 1969, pp. 217-252. For the relationship between cartography and architecture, and the cinematic image, from a feminist and «sensuous-theoretical» perspective, see BRUNO, Giuliana: Atlas of Emotion: Journeys in Art, Architecture, and Film. London, New York, Verso, 2002.

6. In his above-mentioned essay, Lippit has also made a the argument for the cave paintings as anamorphic and animated/animating: «The Lascaux paintings appear to utilize the surface of the cave's walls in such a manner as to suggest not only movement but a singular vantage point. The phenomenon of anamorphosis appears at work in Lascaux if not as an intended method, then as an unintended result.» See LIPPIT, Akira Mizuata: op. cit., p. 26.

7. While too specific to elaborate here on the term «visualization» and its background in computer science, a useful documentation of the very early definition of the term can be found in the report by Mccormick, Bruce H. et al. (eds.): «Visualization in Scientific Computing», Computer Graphics, 21, 6 (1987), New York, ACM SIGGRAPH.

Also, I want to point out the cartographic background of the term as used for the representation of scientific data, evidenced by the pervasiveness of the metaphor of «mapping» in other fields. About visualization principles in cartography, see KraAk, Menno-Jan and Ormeling, Ferjan: Cartography: Visualization of Spatial Data. New York, London, Pearson Education, 2011. For crossings of cartography and other disciplines, see PICKLES, John: A History of Spaces: Cartographic Reason, Mapping and the Geo-Coded World. London, Routledge, 2004. About the consequence of the shift from the image as object to the image as interface for museums, see de RIJCKE, Sarah and BEAULIEU, Anne: «Image as Interface: Consequences for Users of Museum Knowledge», Library Trends, 59, 4 (2011), pp. $663-685$.

8. William Kentridge explains his method in a video released by SFMoMA in 2009 , available on the accompanying website for the 2010 exhibition Five Themes at MoMA. See <http://www.moma.org/interactives/exhibitions/2010/williamkentridge/> (accessed October 2015). About the archival character of Kentridge's work, the 
formally and conceptually, as traces, they evoke the pre-historical and long-hidden cave drawings that Herzog's camera traces (follows) and tracks (records) precisely in his effort to animate them. Herzog, like Kentridge, animates the images. Or, rather, he tracks, or draws out the layers of animation already inherent in the paintings themselves. ${ }^{9}$

As we will see below, the cave paintings themselves also show images «with difference,» in Kentridge's sense, albeit with difference within the same image, for example, when portraying running animals with one body and multiple legs, suggesting movement. These recall Étienne-Jules Marey's chronophotography - an effect that Herzog himself calls «proto-cinema.» In his voice-over he compares the illusion of movement of the layered images to frames of animated movies - which indicates how movement is suggested by the dissection of movement into overlaid frames. Other panels in the cave show images that are overlain with «newer» images with probably thousands of years in between, as the voice-over explains. In this respect, the movie brings another layer to the animation of the paintings: produced by visualizing (and hence, according to my argument, analyzing) transformation and difference not only in temporal, but also in spatial terms - in moving as well as 3D images.

Different as they are in other respects, both Kentridge's animations of still images (drawings) and Herzorg's film that animates the cave paintings are strongly invested in replacing an optic mode of looking by a haptic one. Although there is much scholarship on haptic looking, I limit myself here to those aspects relevant for my case. The term, introduced in I90I by Alois Riegl, has been brought to bear on impressionist painting by Gilles Deleuze. Haptic, from the Greek aptô («touching») is characterized by three related primary features relevant for both Herzog's film and Kentridge's animations. The haptic solicits proximity, inviting viewers to caress the image with the eyes; it is ultimately formless; and in consequence, lines change their function. I take this trifold characterization of the haptic from Mieke Bal who, departing from Deleuze and Guattari, has defined the haptic as enhanced by a «dialectic between form and formlessness» that emerges in the act of approaching the work of art that she analyzes. It is the disappearance of form into formlessness and the emergence and movement of lines that characterizes the haptic encounter. ${ }^{\text {IO }}$ Indeed, the haptic encounter in the case of Herzog's film seems to bring about

layering of techniques and times, and of the mnemonic quality of what he calls tracing, tracking and tracting - a distinction he makes for observing, recording, and «drawing out»-see HECKER, Judith and KENTRIDGE, William: William Kentridge: Trace: Prints From The Museum of Modern Art. New York, Museum of Modern Art, 2010. About his palimpsestic animations, see KRAUSS, Rosalind, (2000) «The Rock: William Kentridge's Drawings for Projection», October, 92 (2000), pp. 3-35.

9. This is an allusion to cel (or cell) animation technique -traditional animation based on a succession of individually hand-drawn frames on celluloid sheets. It raises questions about the role of «layers» in analogue techniques «infecting» digital cinema techniques that lay beyond the scope of this essay. For more in-depth inquiry into cel animation techniques see, for example, THOMPSON, Kristin: «Implications of the Cel Animation Technique», in de Lauretis, Theresa and Heath, Stephen (eds): The Cinematic Apparatus. London, Macmillan Publishers, 1980, pp. 106-120, and RiffeL, Casey: «Dissecting Bambi: Multiplanar Photography, the Cel Technique, and the Flowering of Full Animation», The Velvet Light Trap, 69, 1 (2012): pp. 3-16.

10. BaL, Mieke: Endless Andness: The Politics of Abstraction According to Ann Veronica Janssens. London, New York, Bloomsbury, 2013, p. 92. 
mobility rather than abstraction, in a parallel animation of gaze, surface and lines. The haptic look is particularly solicited by images animated by tracing (Kentridge) - created by following the flow of transition -as well as layering (Herzog)- by exploring the spatial dimension. Tracing can be understood as a haptic form of spatial exploration, and as such engages the more invasive yet paradoxically fundamentally distancing forms of exploration in an oblique polemic. As per Kentridge's method, tracing is an encounter with difference and transformation resulting in movement. It emphasizes space as an emphatically experiential category. Animation as such can be considered a thickening of both space and time in movement. Fred Truniger makes a similar point in his work on what he calls the filmic mapping of dynamic landscape. Commenting on seeing landscape on «experiential» rather than «aesthetic» terms, he considers this distinction as oppositional is problematic. Indeed, is the aesthetic not experiential? It is clearer with temporal specification: experiential temporality rather than aesthetic fixation. ${ }^{\text {II }}$

Seen in these terms, Herzog's film suggests a layering in animation, by literally bringing movement to the surface. Or to be more precise, working with the visual effects of succession as well as depth, making $3 \mathrm{D}$ beside a spatial also a temporal quality, the film proposes the relationality of the visual, in both temporal and spatial terms. A concept of central importance here is the index. Elsewhere, I have argued for an extension of the semiotic sign of the index (following Peirce). This is usually taken as either pointing to the past (the trace) or the present (deixis). I have pointed out how, in tools for navigation on the mobile screen, the index used as tag or digital spatial marker, encapsulates a future-oriented destination. ${ }^{12}$ This destination-index should be understood as a shifting referent, rather than a fixed end-point. This understanding of the index implies that an image can no longer be seen only as a result, a fixed and visual representation, but rather as a temporally layered object for a dialogic and haptic, multi-directional engagement with space and time. The image is now a tool for more (subjective) engagement instead of contemplation of a distant object.

Paradoxically, then, with its emphatically nostalgic and «poetic» overtones, this film about ancient images is perhaps somewhat future-oriented as well, in its conception of imaging as process. In this sense it demonstrates navigation as a cartography in-the-making. This semiotic and performative starting point helps reconsidering the dimensionality of the image -be it still or moving.

Key characteristics of navigation are performativity and process. Inspired by Herzog's film, my point in this essay is thus an understanding of the layered-ness of images in time as well as space. Images are thus not fixed within an opposition of still versus moving -as is perhaps never really the case in filmic projection. Instead, this layeredness emerges in a haptic engagement with the image. As a consequence, the image never stands still. This is, for me, the extended but crucial sense

11. Truniger, Fred: Filmic Mapping: Film and the Visual Culture of Landscape Architecture. Berlin, Jovis Verlagsund Projektburo, 2013, p. 77.

12. Verhoeff, Nanna: Mobile Screens: The Visual Regime of Navigation. MediaMatters. Amsterdam, Amsterdam University Press, 2012. 
of the idea of animation. By both tracing the walls with images as well as showing their spatial layering and the resulting optical effects of moving lines and light, the movie evokes a sense of presence - not only in (unfamiliar) space, but also and very powerfully at the very moment, and in the duration, of happening. This illusion of contemporaneity is a key feature of the time-based experience of the cinematic moving image. It is premised on deferral or temporal disjunction.

This experience of presence and absence, simultaneity and asyncronicity, is indeed quintessentially cinematic. This is perhaps why the visual form of navigation is such a powerful cinematic trope. Here, the movement through the space of the cave is doubled-up, combined with making images move in animation. This occurs through tracing the painted lines on the walls, but also zooming in and following the contours of the rocky surface in its flowing movement to and from the camera. Also, the flickering lights held close to the images bring about another layer of movement in a play of light and shadows. The movements as such are not only lateral, at a regulated and fixed distance, but also explore the irregularity of surface in the form of a haptic caress, following its three-dimensional dynamic face. Hence, this form of animation is emphatically $3 \mathrm{D}$, perhaps even $4 \mathrm{D}$ : in spatial terms by visualizing spatial complexity at the surface, and in temporal terms as taking place in the encounter.

In his conceptualization of a haptic notion of perception that brings together movement and action with visual perception, architect and theorist Lars Spuybroek reflects on the cave as a concept. He refers to the work by Jean Clottes and David Lewis-Williams, who have studied rock paintings in French and Spanish caves. Spuybroek is particularly interested in their observations that the images of animals seem half-finished in paint, yet with light effects of torches shining on the caves' surfaces become «finished,» even animated. As Spuybroek poetically concludes, «the body looking at it 'flies' in.» ${ }^{13}$ To me this underscores how the optical effect of the three-dimensional relief - what he calls the topography of the rocks -infuses the images at the surface with motion in the act of looking. This effect of finishing and, indeed, animating the image Spuybroek compares to the principle of interactivity of, for example, electronic art- a comparison that indeed foregrounds the «liveness» of the image as event in the encounter.

When we look back at the film, we can clearly see how the slow tracing of the painted rock surfaces by the camera is a signature of the film's visual style deployed to show the images not in isolation, but within their material and only partly-accessible spatial context. The explorers/cameras have to tread very carefully on the narrow pathways that provide (and restrict) passage through the space. The slow «stroking» and following the contours of the image surfaces of the subjective camera what the eye of both the explorer and the film viewer do provides both a sense of proximity and intimacy as well as of careful distance. Access and distance coincide

13. Spuybroek, Lars: «The Soft Machine of Vision», The Architecture of Continuity. Rotterdam, V2_Publishing, 2008, pp. 94-111, p. 101. See also CLOTTES, Jean and LEWIS-WILLIAMS, David: The Shamans of Prehistory: Trance and Magic in the Painted Caves. New York, Harry N. Abrahams, 1998. 
in these images that create a relationality between image-object (the cave surfaces) and the image-subject (the eye of the beholder). Thus they make clear that seeing is not physical touching, and that tracing is not framing. They engage difference and refuse visual fixation, spatial dichotomies, and territorial domination. Instead, this engagement is more intimate or dialogic, with the image and its user-viewer as the two interlocutors in an I-you exchange. The desire for haptic encounters and dialogic engagement brings forward a different visual paradigm that deviates from a visual discourse based on distance, difference, and objectification.

The visual technologies involved here are a confrontation, or exchange, between contemporary $3 \mathrm{D}$ cinema and ancient $2 \mathrm{D}$ (but perhaps also already $3 \mathrm{D}$ ) rock painting. These millennia-old drawings are mute and still, but come to life - are animated - in the encounter. In accordance with Peirce's dynamic conception of semiotics, in the relationship the subject, the knowledge producer, becomes vulnerable and changing. The flickering lights and subsequent movement intimate such vulnerability. This entails in some cases an archeological as well as a cartographic logic, dealing with issues of access, deixis, and the haptic aspect of being «in touch,» as I will explain below. The objective seems to be the experience of the exploration and excavation. ${ }^{14}$

Three main and intertwined aspects of the image are central so far: access, deixis and the surface. These three aspects work towards an engagement of the subject with the image at the surface. It is, precisely, the tension at the surface - the tension between closeness and distance that shapes the process of this form of animation. This process is dialogic, because it animates the image through the viewer's presence and response, intellectually, sensory and even physically, to the images in process.

\section{CARTOGRAPHY OF TIME}

In contrast to the more usual conception of the $3 \mathrm{D}$ image as offering a means for heightened spectatorial immersion in the moment, the exploration offered in Herzog's film operates more as an encouragement for spectators to actively engage with a visual imagery of elsewhere and elsewhen. Herzog shows an alternative mode of engagement, also in space, to the passivity allegedly suggested in the metaphor of immersion. His active immersion suggests a form of participating through «accessing» as a dialogic and experiential form of interpretation by exploration, more on the terms of the object itself, rather than the sinking into a different realm or (fictional) world. Hence my preference for the term engagement, of which active immersion would be a variant. A focus on dialogic encounters allows us to sidestep

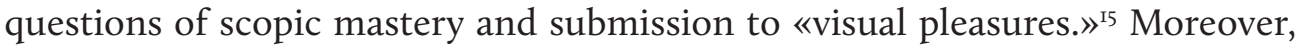
such a revision of immersion into active engagement allows us to investigate how

14. About the role of the subject in Peircian semiotics and the question of experience, see de LAURETIS, Theresa: Alice Doesn't: Feminism, Semiotics, Cinema. Bloomington, IN, Indiana University Press, 1984.

15. I allude here to Laura Mulvey's seminal critique of masculinist modes of looking, although of course, Mulvey wrote about classical Hollywood cinema, and not about 3D documentaries. MuLver, Laura: «Visual Pleasure and Narrative Cinema», Screen, 16, 3 (1975), pp. 6-18. 
technologies of vision are used for, and experienced as creative experimentation and engagement, rather than for an affirmation of the logic of dualism, classification, and separation. ${ }^{16}$

In the mode of an archeological exploration, Herzog's documentary The Cave of Forgotten Dreams is a quintessential travel film, both in a spatial and a temporal sense. The camera operators shoot the film as they descend into the cave, taking the viewer along as they encounter this unfamiliar territory. It provides visual-spatial access to the Chauvet cave - access both in terms of «admittance to» and «contact with» - which was discovered in I994, and, as mentioned above, is inaccessible for the public for preservationist reasons. This detail is relevant, for it gives all viewers a privilege not otherwise available -a trope in virtual travel imagery with a long history. The coincidence of filming and access suggest equality between filmmaker and viewer- albeit a promise falsified by mediation. The lack of explanatory voiceover, and the silence that accompanies many of the images, also contributes to an auratic sense of respectful distance and shared wonderment between explorer/ camera and viewer. Framed as an archeological descent into (geological) deep time and (human) deep history, central to the film -in both its image style and in the (sparse) narrative voice-over explaining this- is the issue of accessibility and epistemological restriction. ${ }^{17}$

This issue is inherent in the delicacy of the spatial integrity of the cave as both place and temporal object, and the precariousness of the knowledge we can have of it, but also in the process of mediation. The awareness of precarity that comes with the privilege already intimates an ethical issue. Literally, the makers of the film are restricted by the conditions of their access and, spatially, by narrow pathways through the cave. Moreover, they get limited time for their own access. The film is self-reflexive in this respect as well. In the exposé the voice-over explains this limitation upon entering the cave, emphasizing its exclusivity and limitation in explicitly auratic terms. Through the medium of $3 \mathrm{D}$ technology, the film democratizes the privilege by sharing the experience of an encounter with times so remote (and «forgotten» as the title suggests) that they are suggested to be from an early stage of humanity. Thus, the film searches for, and along the way suggests insight into what binds us all together, across time and space. This universalizing and perhaps somewhat dramatic and nostalgic ambition notwithstanding, the ambition

16. Theoretical physicist and feminist theorist Karen Barad critiques the separation between «words» and «things» in representationalism inherent in modern scientific thought - a separation that fundamentally complicates knowledge. See BARAD, Karen: Meeting the Universe Halfway: Quantum Physics and the Entanglement of Matter and Meaning. Durham, NC, Duke University Press, 2007. For an interview with Barad and more about New Materialism as a critique of these principles, see DOLPHIJN, Rick and VAN de TUIN, Iris: New Materialism: Interviews and Cartographies. Ann Arbor, MI, Open Humanities Press, 2013.

17. Deep time is a concept used for geologic time, and deep history is a term that looks at the history of human kind from a longer perspective and based on a marking of difference between «history» and «prehistory». Mira Schor, quoted below, uses «deep past» when she discusses the Herzog film. All these terms have in common a spatial metaphor for time and deictically suggest a distance of the past from an «l» in the present. 
of sharing experience is different from a long history of patriarchal and exoticizing imagery of the alterity of elseness. ${ }^{18}$

This sharing of the there-then in a discourse addressed to viewers in the herenow is where the idea of layering comes in. While the title, The Cave of Forgotten Dreams, reflects nostalgically on the distance of the elsewhere and elsewhen, we encounter a sense of temporal layering of place, or placetime, by «considering the deep past's uncanny co-existence with our present» as feminist artist and critic Mira Schor points out. ${ }^{19}$ As such, the movie provides a time travel experience in the true sense: it establishes a relationship with the past through reflection on the question of accessibility of this past in the present, stimulating its viewers to participate in the reflection. It explores not only the space of the cave but also its time in a movie-image excavation that emphasizes the process of opening up the site and animating the painted images of the past in a fragile presence in the present. Herzog's film reflects on, and experiments with, the visualization of a layering of space that re-animates the «still» images that are endowed with movement, animation, with the curves of the walls and the effect of light on these curves. The tracking shots that follow the lines of the images, not just horizontally, but also by tilting and zooming and with the $3 \mathrm{D}$ effect, explore the texture of the image in depth, visualize the «depth-movement» as already intrinsic in the ancient images. The images already have movement in them, but the multi-dimensionality in the encounter is needed for that movement to become visible; for its performativity. The film needs the tools offered by 3D moving-image technology to deal with these layers, in a fashion that, indeed, may warrant the tweaking of McLuhan's canonical phrase into "The Medium is the Method.»"

One evocative aspect of (moving) $3 \mathrm{D}$ images is a heightened visual effect of spatial continuity with the image-space for the spectator, a continuity that produces a direct sensual impression of tangibility and immediacy. It is often pointed out that the vertical depth of the image accentuates an immersive effect, exemplified in highspeed chase scenes, or shots where the spectator seems to be plunged into the depths of space. Herzog's film proposes instead a haptic approach to three-dimensional images by explorative spatial tracking and a (horizontal) tracing of surfaces. It is in the middle ground, somewhere between self-effacing thrusts into space, into passive immersion, and the establishment of a self-affirming and dominant fixed point of view, that this technique also allows for more intimate, temporary haptic encounters. $3 \mathrm{D}$ imagery knows many forms and usages indeed. In my work on early

18. Another project that combines archeology and innovative, immersive visualization technologies in the case of cave exploration is Sarah Kenderdine's project in the Mogao Grottoes, Gansu Province, China. See KENDERDINE, Sarah, «Pure Land': Inhabiting the Mogao Caves at Dunhuang,» in Curator: The Museum Journal, Volume 56, Issue 2, pp. 199-218, April 2013.

19. SCHOR, Mira: «Wonder and Estrangement: Reflections on Three Caves», parts 1 and 2 of 3, online essay <http://ayearofpositivethinking.com/2011/07/28/wonder-and-estrangement-reflections-on-three-caves-parts-12-of-3/> (uploaded July 2011).

20. Verhoeff, Nanna: «The Medium is the Method: Locative Media for Digital Archives», in Eckel, Julia et al. (eds.) (Dis)Orienting Media and Narrative Mazes. Bielefeld: Transcript, 2013, pp. 17-30. Janet Murray has used this phrase as well in her examination of the analysis of interaction design. See MurRAY, Janet: Inventing the Medium: Principles on Interaction Design as a Cultural Practice. Cambridge, MA, MIT Press, 2013, p. 16. 


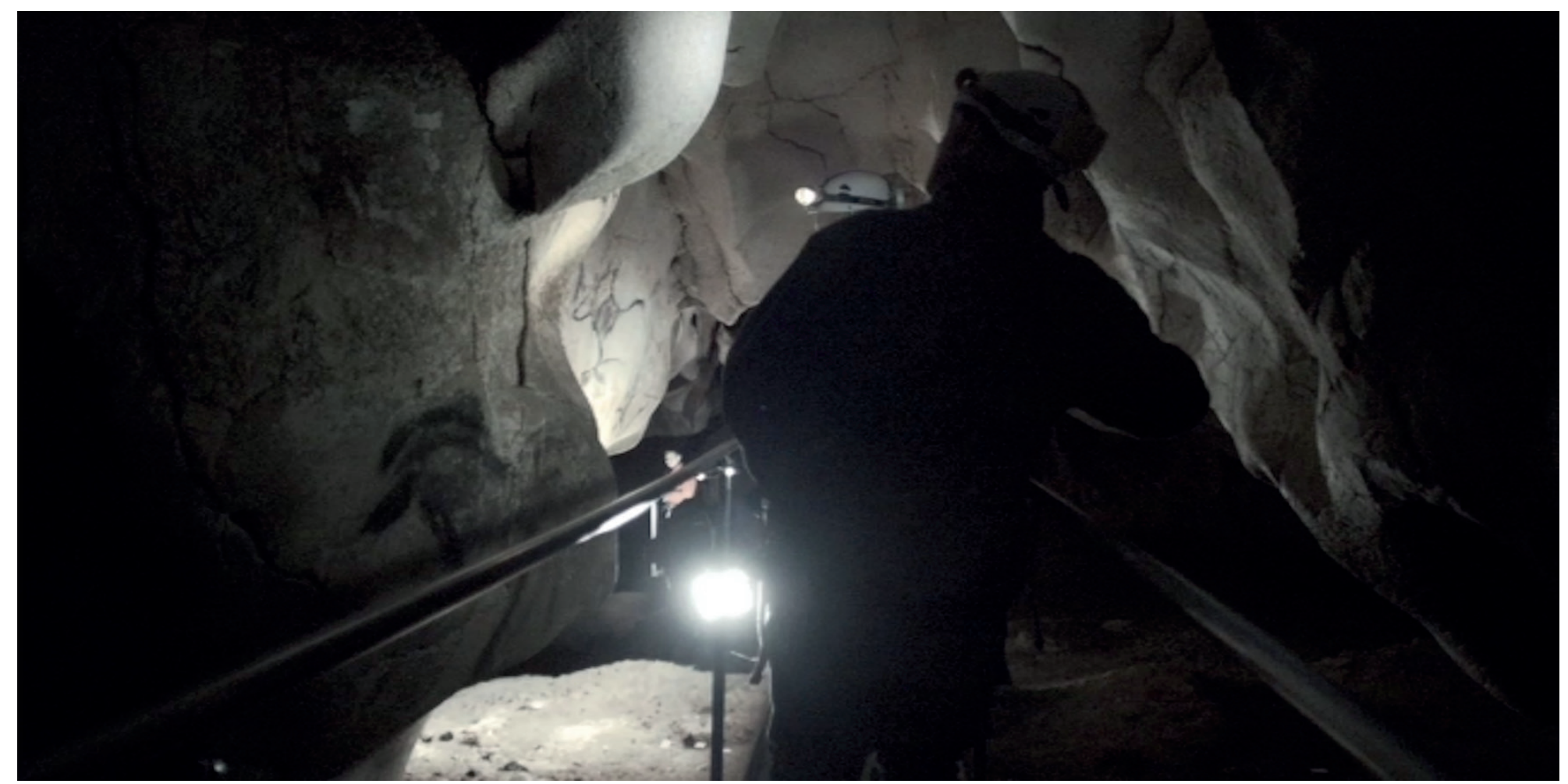

FIGURE 2: HIGHLY INTIMATE SHOT OF THE CAMERA THAT FOLLOWS THE EXPLORERS ON THE NARROW PATHWAYS, BRINGING THE CAMERA CLOSE, YET AT A CAREFUL DISTANCE, TO THE CONTOURS AND CURVES OF THE PAINTED ROCK SURFACE.

cinema I have pointed out how the aesthetic of the sublime in landscape depiction sets up a dual ambition of submission in awe and wonder, and a resulting desire for visual mastery. ${ }^{21}$ This ambivalence results in tensions so effectively organized in, for example, high-paced, $3 \mathrm{D}$ action movies, very similar in effect to the so-called phantom rides of early cinema. These are point-of-view shots of passing landscape taken from a moving vehicle such as a train or car. As such, they boast about the technological possibilities of travel and the moving image together. What the use of $3 \mathrm{D}$ technology as exploratory rather than immersive counters is this rather long tradition of visual challenge and its overcoming through domination -called the sublime. $^{22}$

For example, before, and contemporary to early cinema, the immensely popular 3D stereographs depicted locations that were meaningful for their capacity to offer a point of view, the spectacle that results, and the affective response they elicit.

21. Verhoeff, Nanna: The West in Early Cinema: After the Beginning. Film Culture in Transition, Amsterdam, Amsterdam University Press, 2006.

22. For the sublime in aesthetic theory, see HIPPLE, Walter J.: The Beautiful, the Sublime, and the Picturesque in Eighteenth-Century British Aesthetic Theory. Carbondale, IL, Southern Illinois University Press, 1957. About phantom rides in early cinema and their analogs in contemporary visual culture, see VERHOEFF, Nanna: «Pointing Forward, Looking Back: Reflexivity and Deixis in Early Cinema Installations», in Gaudreault, André, DuLAC, Nicolas and Hildalgo, Santiago (eds.): The Blackwell Companion to Early Cinema. Oxford: Blackwell Publishing, 2012, pp. 568-586. 
Through this foregrounding of temporal and spatial layering the film aligns itself with such a construction of the image-subject in contact with the object through haptic looking. In this respect, it resonates with well-established approaches in film theory that have criticized and questioned the inherent power of visuality, albeit in very different ways. The foregrounding of deixis -for example by the subjective shots and the whole issue of accessibility of the space- opens up a dialogue, not only between viewer and object -the cave paintings, the walls and surfaces, and the voices- but also with a variety of approaches to film analysis. To stay with my interest in deixis, as the positioning of the subject this can be included in different approaches to the power of images. For example, if we follow a traditional psychoanalytical approach we can argue how deictic address of the image both gives and takes: providing voyeuristic pleasures yet enslaving the viewer in passive acceptance of the limitations of the pre-structured gaze. If we adopt a phenomenological perspective, however, we can see deixis as opening up a dialogic and haptic engagement with the moving image. This implies an entirely different relationship between subject and object and shifts the question of power from visual domination to visual engagement; from a third-person storytelling about an object to a first-person/second-person exchange of positions. Deixis is the key instrument to effectuate such a situation of exchange. And layering makes it emphatically haptic. ${ }^{24}$

This performativity can be understood as the construction of presence. This may resolve what Mary Ann Doane suggests to be a spatiotemporal disorientation in confrontation with the moving image in projection, when she writes that «the perception of the moving image takes place somewhere between the projector and screen, and the temporary, ephemeral nature of that image is reaffirmed by its continual movement and change. ${ }^{25}$ Pepita Hesselberth sees this as fundamental of a «tangibility-effect» of cinematic deixis:

As a projectable property then, presence - understood as the perception of self-existence, of 'me' - arises from the embodied interactions afforded within a given environment, in real-time and real-space. [...] In fact, I would argue that a focus on presence intimates a conception of materiality that is much more in sync with the cinematic project as a whole, as it picks up where the fear of the dematerialization of the image associated with luminous projection has left us: at the loss of the image's indexical grounding in a material object - be it celluloid or, as in the case of the optical toy, in the «afterimage. $»^{26}$

The deictic approach to the image and a reconsideration of its materiality opens up an understanding of a thickening of time and space in the encounter with the moving image.

24. In feminist philosophy, this difference has been put forward by CODE, Loraine: What Can She Know? Feminist Epistemology and the Construction of Knowledge. Ithaca and London, Cornell University Press, 1991, and CODE, Lorraine: Rhetorical Spaces: Essays on Gendered Locations. New York, Routledge, 1995.

25. DOANE, Mary Ann: «The Location of the Image: Cinematic Projection and Scale», in Modernity», in EAMON, Christopher and Douglas, Stan (eds): The Art of Projection. Stuttgart, Hatje Cantz, 2009, pp. 151-165, p. 152.

26. Hesselberth, Pepita: Cinematic Chronotopes: Here, Now, Me. London and New York, Bloomsbury, 2014, p. 96. 
Critical thinking about performativity and the image brings out the intricate relationship between meaning and practice, knowledge systems and cultural forms. The connection between the very different cultural realms (such as entertainment, art, and science) and technologies of vision, such as the ones I invoke in this essay -photographic stereographs, $3 \mathrm{D}$ documentary cinema, and effectively also cave-painting and stop-motion animation- demonstrate how pervasive this relationship is. The performativity of these media can be seen as a different mode of exploration, one not steered by the desire for domination but rather for encounter; access earned through deictic engagement. And that is, precisely, how Herzog's film establishes contact with a long-gone past on the surface of the image. This is, literally, a cartography of time - a moving one.

\section{TENSIONS AT THE SURFACE}

As a 3D travelogue, Herzog's film addresses the intricate relationship between cultural tropes, of which the association with gender of certain epistemic and psychic attitudes is a major one, and epistemological ambitions in the use of media technologies - the tendency to use $3 \mathrm{D}$ for visual boasting. Moreover, it is an example of those media practices that address questions about space and mobility.

The moving images shot while entering and exploring the cave provide a hapticvisual encounter with the materiality of the place. They visualize how the paintings in the cave themselves are a three-dimensional play with the texture and relief of the rocky surface. The textural materiality of the cave, in fact, seems to animate the drawings on them. As mentioned above, these layered images of different stages of (arrested) movement within one image («frame») recall Étienne-Jules Marey's chronophotography. We can now see Marey's chronophotographic images as a Wittgensteinian relative of the chronocartography, or the cartography of time we are looking at here. In both, the overlay of multiple exposures of moving bodies within a single frame constitutes an anatomy -if not a cartography- of the body in motion. ${ }^{27}$

In the prominence of a tracing of surfaces and a folding of showing into exploring, I see a figuration of the argument I am articulating here. The film performs an analysis of the tensions between stillness and motion, between $2 \mathrm{D}$ and $3 \mathrm{D}$, between representation and performativity, and between the optic and the haptic. In this sense, the slow lingering and exploring camera invites, or even allegorically produces a multi-dimensional «textural» analysis - to take my cue from, but also extend

27. I want to point out this issue of still and moving image that we can approach from an indexical perspective. However, the scope of this essay does not permit me to expand here on the comparison of this still-animation in multiplicity, and the palimpsestic animation of Kentridge. On Marey and the index in this form of still-animation, see also DoAne, Mary Ann: «Temporality, Storage, Legibility: Freud, Marey, and the Cinema», Critical Inquiry, 22, 2 (1996), pp. 313-343, and DoAne, Mary Ann: Emergence of Cinematic Time: Modernity, Contingency, and the Archive. Cambridge, MA: Harvard University Press, 2003. 


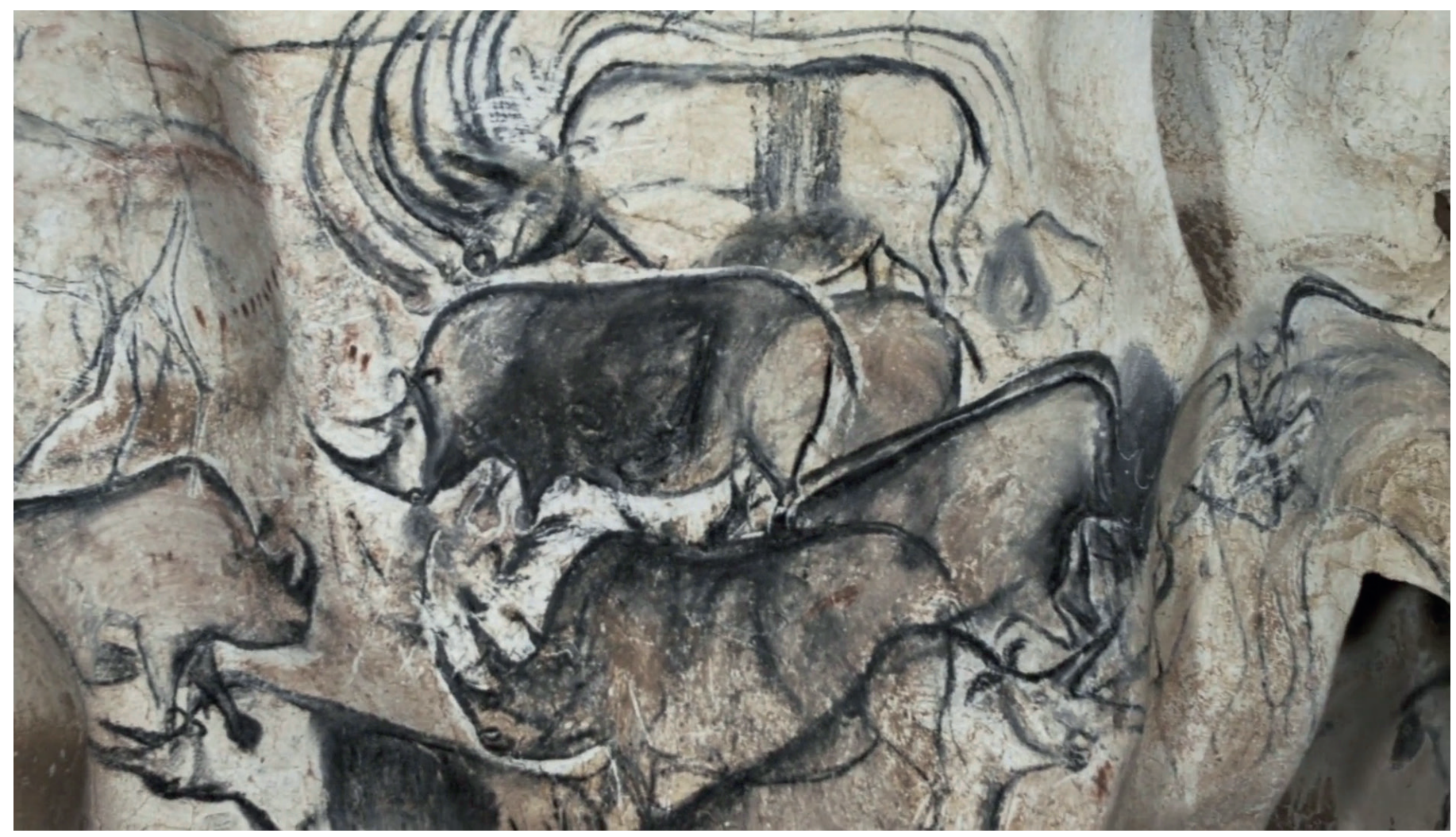

FIGURE 4: DETAIL OF LAYERED IMAGES OF RUNNING ANIMALS, VISUALIZING MOVEMENT BY OVERLAYING IMAGES IN «DIFFERENCE.»

Jennifer Barker's proposal for this type of analysis via a tactile engagement with moving-images-not just of the cave art, but also of the movie images themselves. ${ }^{28}$

I contend that the movie experiments with performing a textural analysis of the cave as it investigates the texture and the dimensionality of the rock paintings. Moreover, it is the duration in movement and the experience of space in time that suggests a fourth dimension. In playing with dimensions, it tests the difference between line and volume, figure and materiality, stillness and animation. Moreover, the explorative character of the display of images, and the ensuing haptic encounter with their texture may seem to reflect the often-made distinction between an optical distanced gaze that is contemplative, and a haptic engagement at the surface, which is more experiential. And as Laura Marks has argued, such an engagement characterizes the specificity of optic versus haptic images. ${ }^{29}$

However, within a framework of exploration and experimentation as performative aspects of animation-in-navigation, this distinction is put under tension. At the heart of the visual regime of navigation, then, is the mobilization of haptic, dialogic relationality. It is in navigational and haptic engagement that the image becomes

28. BARKER, Jennifer: The Tactile Eye: Touch and the Cinematic Experience. Berkeley, CA, University of California Press, 2009.

29. MARKs, Laura: Touch: Sensuous Theory and Multisensory Media, Minneapolis, University of Minnesota Press, 2002. 
layered and animated. Fixatives of binary opposition, and dualistic notions of difference, visibility, and knowledge, are challenged in this tracing at the surface. 


\section{BIBLIOGRAPHY}

BAL, Mieke: Endless Andness: The Politics of Abstraction According to Ann Veronica Janssens. London and New York, Bloomsbury, 2013.

BARAD, Karen: Meeting the Universe Halfway: Quantum Physics and the Entanglement of Matter and Meaning. Durham, NC, Duke University Press, 2007.

BARKER, Jennifer: The Tactile Eye: Touch and the Cinematic Experience. Berkeley, CA, University of California Press, 2009.

Benjamin, Walter: «The Work of Art in the Age of Mechanical Reproduction», Illuminations. New York, Schocken, 1969, pp. 217-252.

Bruno, Giuliana: Atlas of Emotion: Journeys in Art, Architecture, and Film. London, New York: Verso, 2002

-, Surface: Matters of Aesthetics, Materiality. Chicago, IL, University of Chicago Press, 2014.

Christie, lan: «Will the 3D Revolution Happen? A Brief Perspective on the Long History of Stereoscopy (with Special Thanks to Eisenstein and Bazin)» in Annie van den Oever (ed.), Technē/Technology, Amsterdam: Amsterdam University Press, 2015, pp. II5-I35.

Clottes, Jean and Lewis-Williams, David: The Shamans of Prehistory: Trance and Magic in the Painted Caves. New York, Harry N. Abrahams, 1998.

CoDe, Loraine: What Can She Know? Feminist Epistemology and the Construction of Knowledge. Ithaca and London, Cornell University Press, I99I.

-, Rhetorical Spaces: Essays on Gendered Locations. New York, Routledge, I995.

de LaUretis, Theresa: «Semiotics and Experience», Alice Doesn't: Feminism, Semiotics, Cinema. Bloomington, IN: Indiana University Press, I984.

de RijCKe, Sarah and BeAlieu, Anne: «Image as Interface: Consequences for Users of Museum Knowledge», Library Trends, 59, 4 (20II), pp. 663-685.

DoANE, Mary Ann: «The Location of the Image: Cinematic Projection and Scale», in Modernity», in Eamon, Christopher and Douglas, Stan (eds): The Art of Projection. Stuttgart, Hatje Cantz, 2009, pp. I5I-I65.

-, Emergence of Cinematic Time: Modernity, Contingency, and the Archive. Cambridge, MA, Harvard University Press, 2003.

DolPHIJN, Rick and VAN de TuIN, Iris: New Materialism: Interviews and Cartographies. Ann Arbor, MI, Open Humanities Press, 2013.

Hecker, Judith and Kentridge, William: William Kentridge: Trace: Prints From The Museum of Modern Art. New York, Museum of Modern Art, 2010.

Hesselberth, Pepita: Cinematic Chronotopes: Here, Now, Me. London and New York, Bloomsbury, 2013 .

Hipple, Walter J.: The Beautiful, the Sublime, and the Picturesque in Eighteenth-Century British Aesthetic Theory. Carbondale, IL, Southern Illinois University Press, 1957.

Kenderdine, Sarah, «'Pure Land': Inhabiting the Mogao Caves at Dunhuang,» in Curator: The Museum Journal, 56, 2 (2013), pp. 199-218.

KIM, Jihoon: «Introduction: Three dimensionality as a heuristic device», Convergence: The International Journal of Research into New Media Technologies, I9, 4 (2013), pp. 39I-395.

KraAk, Menno-Jan and Ormeling, Ferjan: Cartography: Visualization of Spatial Data. New York, London, Pearson Education, 20II. 
Krauss, Rosalind: «The Rock: William Kentridge’s Drawings for Projection», October, 92 (2000), pp. 3-35.

LipPIT, Akira Mizuta: «Arche Texts: Lascaux, Eros, and the Anamorphic Subject», Discourse, 24, 2 (2002), pp. 18-29.

MARKs, Laura: Touch: Sensuous Theory and Multisensory Media. Minneapolis, University of Minnesota Press, 2002.

Mccormick, Bruce H. et al. (eds.): «Visualization in Scientific Computing», Computer Graphics, 2I, 6 (I987) New York, ACM SIGGRAPH.

Mulvey, Laura: «Visual Pleasure and Narrative Cinema», Screen, I6, 3 (I975), pp. 6-I8.

MurRaY, Janet: Inventing the Medium: Principles on Interaction Design as a Cultural Practice. Cambridge, MA, MIT Press, 2013.

PICKLES, John: A History of Spaces: Cartographic Reason, Mapping and the Geo-Coded World. London, Routledge, 2004.

Riffel, Casey: «Dissecting Bambi: Multiplanar Photography, the Cel Technique, and the Flowering of Full Animation», The Velvet Light Trap, 69, I (2012), pp. 3-16.

SCHOR, Mira: «Wonder and Estrangement: Reflections on Three Caves», parts I and 2 of 3, online essay <http://ayearofpositivethinking.com/20II/07/28/wonder-and-estrangementreflections-on-three-caves-parts-I2-of-3/> (uploaded July 20II).

SPUyвroek, Lars: «The Soft Machine of Vision», The Architecture of Continuity. Rotterdam, V2_Publishing, 2008, pp. 94-III.

TRUNIGER, Fred: Filmic Mapping: Film and the Visual Culture of Landscape Architecture. Berlin: Jovis Verlags- und Projektburo, 2013.

VerhoefF, Nanna: The West in Early Cinema: After the Beginning. Film Culture in Transition. Amsterdam, Amsterdam University Press, 2006.

-, Mobile Screens: The Visual Regime of Navigation. MediaMatters. Amsterdam: Amsterdam University Press, 2012.

-, «Pointing Forward, Looking Back: Reflexivity and Deixis in Early Cinema Installations», in Gaudreault, André, Dulac, Nicolas and Hildalgo, Santiago (eds.): The Blackwell Companion to Early Cinema. Oxford, Blackwell Publishing, 20I2, pp. 568-586.

-, «The Medium is the Method: Locative Media for Digital Achives», in Eckel, Julia et al. (eds.): (Dis)Orienting Media and Narrative Mazes. Bielefeld, Transcript, 2013, pp. 17-30. 
AÑO 2016

NUEVA ÉPOCA

ISSN: $1130-4715$

E-ISSN 2340-1478

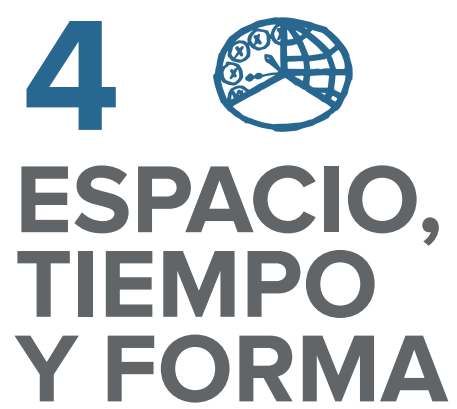

Dossier by Mieke Bal: Art Moves: Performativity in Time, Space and Form / El Arte (Se) Mueve: Performatividad en el Tiempo, el Espacio y la Forma por Mieke Bal

15

MIEKE BAL (GUEST EDITOR)

Movement and the Still Image / El movimiento y la imagen fija

\section{First reflections on movement}

4.5 Miguel Ángel Hernández Navarro

Retorcer el tiempo: Fernando Bryce y el arte de historia / Twisting Time: Fernando Bryce's Art of History

7

NANNA VERHOEFF

Surface Explorations: 3D Moving Images as Cartographies of Time / Exploraciones de superficie: Imágenes 3D en movimiento como cartografías del tiempo

\section{Ramón Salas Lamamié de Clairac}

El tiempo dialéctico: la cuarta era de la imagen / Dialectical Time: The Fourth Era of the Image

17 Mar García RANEdo

Desplazamientos (in)móviles / (Im)mobile Displacements

\section{Technique: «mistakes» as movement}

143 Jose Manuel Garcia Perera

El movimiento como simulacro en el mundo virtual: Michael Betancourt y el arte de la inmediatez / Movement as Simulacrum in the Virtual World: Michael Betancourt and the Art of Immediacy

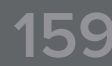

ERNST VAN ALPHEN

Exoticism or the Translation of Cultural Difference / Exotismo o la traducción de la diferencia cultural

\section{Mónica Alonso Riveiro}

Arqueología de la ausencia de Lucila Quieto: un viaje hacia la imagen imposible / Archaeology of Absence of Lucila Quieto: a Trip to the Impossible Image

\section{AYLIN KURYEL}

Disorienting Images: A Bust with Multiple Faces / Imágenes que desorientan: una instalación con múltiples caras
219

AMPARO SERRANO dE HARO

The Movement of Miracles / El movimiento de lo milagroso

Sharing space: discourses of display

235 Elisa de Souza Martínez

Ethnographic Image: In and Out of the Exhibition Space / La imagen etnográfica: dentro y fuera del espacio expositivo

\section{NOA ROEI}

Making National Heritage Move: Ilya Rabinovich's «Museutopia» Projects / Dinamizando el patrimonio nacional: el proyecto «Museutopia» de llya Rabinovich

279 FERNANDO de FELIPE \& IVÁN Gómez

Cronoendoscopias: un viaje alucinante al interior del cuerpo humano / Chronoendoscopies: Imagining a Trip inside the Human Body

\section{Being part of it: affect and the body}

309 JefFrey MANOEL PIJPERS

Affective Resonance: The Moving Potential of Music in Gilberto Gil's «Aquele Abraço» / Resonancia afectiva: el potencial dinámico de la música en «Aquele Abraço» de Gilberto Gil

329

LAIA MANONELLes MONER

Micro-utopías de lo cotidiano, espacios de encuentro en el arte relacional: una aproximación a ciertas acciones de Marina Abramović y Tino Sehgal / Micro Utopias of the Quotidian, Meeting Spaces in Relational Art: An Approach to some Performances of Marina Abramović and Tino Sehgal

351

PATRICIA LIMIDO \& HeRvé Regnaud

Les racines de l'œuvre : puissance émotionnelle et forme artistique. Deux examples de land-art en France / Roots of Art: Emotional Impact and Artistic Form. Two Cases of Land-Art in France

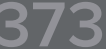

Clara LAguillo

Hibridación de medios en la confluencia de forma, tiempo y espacio: de la Danse Serpentine al Capturing Dance / Hybridization of Artistic Media on the Crossroad of Shape, Time and Space: From Danse Serpentine to Capturing Dance 


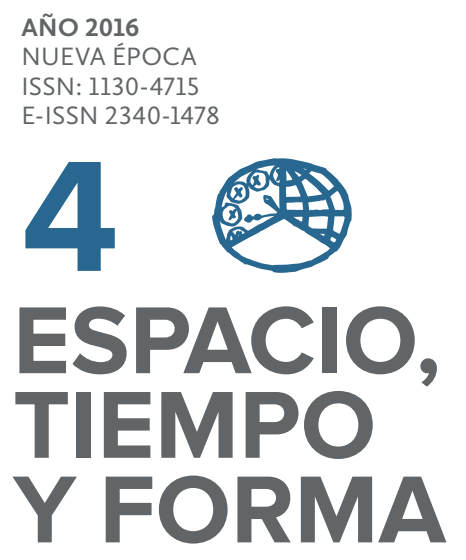

Miscelánea · Miscellany

\section{RaImundo Moreno Blanco}

Aportaciones a la arquitectura y la historia del monasterio del Sancti Spiritus de Ávila / Contributions to the Architecture and History of the Monastery of Sancti Spiritus in Ávila

1.17 José Manuel Almansa Moreno

Estudio y recuperación de la Iglesia de San Lorenzo, Úbeda (Jaén) / Study and Recovery of the Church of San Lorenzo, Úbeda (Jaén)

\section{Manuel Gil Desco}

Imágenes de la locura en la Edad Moderna: escarnio y máscara en el discurso del poder / Images of Madness in the Modern Age: Derision and Mask in the Discourse of the Power

483 Ignacio josé López HeRnández

El Cuerpo de Ingenieros Militares y la Real Junta de Fomento de la isla de Cuba. Obras públicas entre 1832 y 1854 / Spanish Military Engineers and the Real Junta de Fomento at the Island of Cuba. Public Works between 1832 and 1834

\section{9}

\section{NOELIA FERnÁNDEZ GARCíA}

La labor reconstructora de Francisco Somolinos en Langreo, Asturias: La iglesia parroquial de Santiago Apóstol / The Rebuilding Task of Francisco Somolinos in Langreo, Asturias: The Parish Church of Santiago Apostol

\section{Rocío GARRIGa InAREjOS}

Espacio resonantes: del paisaje sonoro de las trincheras a la escucha del silencio en Alfonso Reyes y John Cage / Resonant Spaces: From the Soundscapes of the Trenches to the Hearing of Silence in Alfonso Reyes and John Cage

\section{Reseñas · Book Review}

551 Jose Antonio Vigara Zafra

Vigo Trasanco, Alfredo: La ciudad y la mirada del artista. Visiones desde el Atlántico. Santiago de Compostela, Teófilo, 2014.

555 Jesús Ángel SÁnCHEZ GARCíA

Alonso Pereira, José Ramón (dir.): Modernidad y contemporaneidad en la arquitectura de Galicia. Universidad de La Coruña, La Coruña, 2012.

\section{Joaquín Martínez Pino}

Gimeno, María y Collazos, Raquel (coord.): Paradores de Turismo. La colección artística. Madrid, Paradores de Turismo, Fundación Mapfre, 2015. 